\title{
The Wood, the Trees, or the Forest? Carbon in Trees in Tasmanian State Forest: A Response to Comments
}

\author{
M. T. Moroni, T. H. Kelley, M. L. McLarin, and S. M. Read \\ Forestry Tasmania, 79 Melville Street, Hobart, TAS 7000, Australia \\ Correspondence should be addressed to M. T. Moroni, martin.moroni@forestrytas.com.au
}

Received 10 August 2011; Accepted 3 October 2011

Copyright $\odot 2012$ M. T. Moroni et al. This is an open access article distributed under the Creative Commons Attribution License, which permits unrestricted use, distribution, and reproduction in any medium, provided the original work is properly cited.

Recently we presented data on the amount and distribution of standing-tree carbon on $1.5 \mathrm{M}$ ha of Tasmanian State forest (Moroni et al. 2010) and deduced that the concept of carbon-carrying capacity (CCC) could usefully be applied at the site level but not at the landscape level in disturbance-driven wet eucalypt forest ecosystems. The recent response in this journal of Dean (2011) perpetuates the confusion between site-level CCC and attainable landscape-level C stocks, but mostly comprises material not at all relevant to the data and concepts presented by Moroni et al. (2010). Here, we rebut the response of Dean (2011) to the substance of our original analysis, in regard to the CCC of forests subject to disturbance, processes of ecological succession with and without disturbance, the use of Forest Class inventory datasets, and old-growth forest as a reference state. We respond to the wider issues raised by Dean (2011) by noting that the carbon footprint of active forest management needs to consider not the long-term landscapeaverage $\mathrm{C}$ stocks attainable under natural or anthropogenic disturbance regimes, but also the carbon stock in wood products, and furthermore the carbon emissions mitigation resulting from the use of timber in place of resources with higher greenhouse-gas emissions.

\section{Introduction}

Moroni et al. [1] used a large inventory dataset from $1.5 \mathrm{M}$ ha of Tasmanian State forests to determine the distribution of standing-tree carbon (C) stocks across forest types and age classes. The total mass of $\mathrm{C}$ on this estate was estimated at $163 \mathrm{Tg}$. Although the highest $\mathrm{C}$ densities $\left(\mathrm{Mg} \mathrm{ha}^{-1}\right)$ occurred in the tallest mature wet eucalypt forest of highest crown cover, this forest type represents only $0.2 \%$ by area of state forest-more typical, and containing the majority of the total C stock, were shorter mature forests with lower crown cover, rainforest, and forests containing regrowth or silvicultural regeneration. Moroni et al. [1] used the range of forest classes, types, and ages in this dataset to illustrate the ecological impossibility of attaining or maintaining theoretical C saturation in landscapes containing wildfire-generated forests: conversion of an entire landscape permanently to mature eucalypt forest (that stores the most C) would first require fire to convert existing mixed forest and rainforest back to eucalypt forest, then exclusion of fire while eucalypt forests mature, then prevention of the subsequent progression of eucalypt forests to less C-dense rainforest.

Few of the comments of Dean [2] were in fact related to the above content, with the author instead presenting his views on a range of different and often contentious matters in regard to forestry and climate change. In particular, Dean [2] assumes that changes in forest $\mathrm{C}$ storage resulting from forest management represent the only $\mathrm{C}$ footprint of the forest industry, and overlooks the role of wood products in greenhouse-gas mitigation through $\mathrm{C}$ storage and through reducing emissions from fossil fuel usage (using wood to replace other resources), as well as the impact of the global trade in wood products on forest management decisions. These latter roles are widely recognized as having important roles in greenhouse gas mitigation [3-5].

Here we refocus the discussion on the actual objectives, data, and analyses of Moroni et al. [1], and respond to the relevant comments and assertions of Dean [2]. We also briefly give context to the role of forest management in greenhouse-gas mitigation and respond to some of the 
comments of Dean [2] related to the Tasmanian forest industry.

\section{Carbon Storage in Forests}

The Australian public discourse around forest $\mathrm{C}$ storage often invokes forest types associated with very large trees and $\mathrm{C}$ stocks [6] but which are atypical across the landscape, and in any case are predominantly in reserves $[7,8]$. Generalising from these very tall, wet, mature eucalypt forests overestimates actual and potential forest $\mathrm{C}$ storage across the landscape, with most forests in fact able to store substantially less C [9]. The first objective of Moroni et al. [1] was thus stated as "to improve understanding of forest $\mathrm{C}$ stocks at the landscape level in Tasmanian State forest using an inventorybased analysis of $\mathrm{C}$ in standing live and dead trees, and examine carbon in forest by Forest Class, forest type, elevation, and land-use classes." In contradiction to the assertion of Dean [2], we do accept the value of previous measurements in tall, wet, C-rich forest, but our analysis showed that additional data is required from a wider variety of productivity and cover types for estimation of landscape-level forest Cstocks and the actual potential of forests to store C.

The second, and related, objective of Moroni et al. [1] arose from the difficulty in applying the parameter carboncarrying capacity (CCC) across landscapes containing eucalypts at various stages of their fire disturbance cycle, and was stated as to "estimate the carbon carrying capacity of Tasmanian State forest and explore the methods required to achieve and maintain carbon carrying capacity in Tasmanian State forest." In spite of its original definition, the CCC concept is typically associated with stands of old, C-rich forests, and thus overestimates potential C stocks when applied to landscapes containing forests of a range of ages following natural or anthropogenic disturbance. Specifically, CCC is of dubious relevance to management where the forest with highest $C$ stocks is not ecologically stable: wet eucalypt forests are susceptible either to fire or to succession to rainforests with lower $\mathrm{C}$ density.

2.1. Carbon-Carrying Capacity of Disturbance Forests. Eucalypt regeneration strategies vary considerably [10], including requirements for disturbance of various degrees of severity. Tall, wet eucalypt forest systems are among the most productive, high-quality forests in south-eastern Australia, extending in a discontinuous arc from southern Queensland to Tasmania, and many require severe site disturbance to regenerate $[10-12]$. Drier eucalypt forests show less reliance on severe site disturbance for regeneration. Disturbance in wet sclerophyll forests is often but by no means always stand-replacing $[11,13]$, whereas disturbance dynamics in drier sclerophyll forests are generally gap-driven and not stand-replacing.

Dean [2] unfortunately reinforces the confusing relationship of CCC to wildfire. Roxburgh et al. [14], Mackey et al. [15], and Keith et al. [16] define CCC as "the mass of C able to be stored in a forest ecosystem under prevailing environmental conditions and natural disturbance regimes, but excluding anthropogenic disturbance." The inclusion of the phrase "and natural disturbance regimes" suggests that time since fire is accounted for in some way, but instead CCC has regularly been calculated as the maximum potential $\mathrm{C}$ that a forest can store, that is, solely in relation to mature forests. Estimates of the additional potential C storage capacity of forested landscapes are then presented as the difference between current forest $\mathrm{C}$ stocks and those anticipated if all sites in the landscape were simultaneously occupied by mature, C-rich forests. This approach might work in drier or more open eucalypt forests not subject to stand-replacing wildfire and that would always naturally support a proportion of older trees, but does not capture the impact of disturbance history on the landscape-level age-class patterns of wetter eucalypt forests [17]. Large wildfires, as typified by those on the south-east Australian mainland in 2003, 2006, and 2009 [18], always keep a portion of the wet eucalypt forest area in younger age classes and below maximum potential $\mathrm{C}$ storage, and it is not realistic for the total area of these forests to be simultaneously mature and at their CCC. CCC thus cannot be both values simultaneously-a landscape or temporal average including fire effects (as the definition might suggest) and a local and temporary stand maximum (as CCC is generally calculated). Even though Dean [2] acknowledges wildfire may be "intrinsic to both the standard definition of CCC and to the time-based average method of determining carbon budgets for forest activities," this is then ignored in the incorrect generalisation of CCC values across the landscape.

In his concluding remarks, Dean [2] appears to agree when he criticises Moroni et al. [1] for "their unnecessary redefinition of CCC and their use of C saturation at a landscape-scale rather than its usual usage over a specific duration for a specific forest stand." However, only 2 sentences later Dean himself applies CCC at the landscape scale when he writes "the estimated C deficit in Tasmanian State forests (the amount below its CCC) due to commercial forestry is currently $29( \pm 4) \mathrm{Tg}$." This internal contradiction is the best example of the flaw in the logic. Dean [2] needs to decide whether he is using CCC as a stand parameter or a landscape parameter, because in disturbance-driven ecosystems-and especially in extreme cases of these such as wet eucalypt forests-CCC differs substantially between the stand level and the landscape level.

We thus do not disagree with the definition or application of CCC for individual forest sites and have not attempted to redefine this term, as asserted by Dean [2], but we do disagree with how CCC has been applied at a landscape level in disturbance forests, and its use to calculate some theoretical deficit in $\mathrm{C}$ stocks due to management at the estate level. The dynamic nature of these ecosystems and their C stocks in time and space prevents all stands across a landscape reaching stand-level CCC at the same moment, prevents any stand from remaining at its CCC indefinitely, and makes a nonsense of the goal of managing for stand-level CCC at the landscape scale [19]. It would be preferable to use the term theoretical carbon saturation sensu Nabuurs et al. [20] at the landscape level, restricting CCC to the stand or site level. This would be ecologically sensible, and also would prevent the illogical situation where mature forest sites could carry more C than their calculated CCC. 
2.2. Ecological Succession to Rainforest. Cool-temperate rainforests of SE Australia are comprised of considerably smaller trees than the wet eucalypt forest they replace [21-23], and this transition from eucalypt forest to rainforest is associated with a loss of standing-tree C [1]: forests containing trees of large dimensions are the key to large forest-C stocks [24]. This transition can occur without the "higher stand densities" surmised by Dean, and instead it often involves premature senescence of the eucalypt overstorey. Thus, Dean is not necessarily correct when he writes "the biomass of oldgrowth mixed-forests, being a superposition of two forest types, is likely to be higher than that of each component separately"; instead, the wet sclerophyll-mixed forest-rainforest successional pathway is associated with progressive loss of the tallest and largest trees on the site (and loss of C), not simply the addition of a rainforest understorey.

Dean [2] is also incorrect in asserting that we argue that a reduction in tree dimensions with ecological succession only occurs in Tasmania: it in fact occurs in more instances than Dean [2] provides, but nevertheless these relatively few instances are atypical of more common ecological development where later successional species attain dimensions equivalent to or larger than early successional species [25, 26]. Dean [2] is also incorrect in asserting that Moroni et al. [1] indicate wet eucalypt forest will transition to rainforest only with the cessation of timber harvesting: this transition occurs in the absence of disturbance, including wildfire [2123].

2.3. Inventory Datasets. Dean [2] provides a CCC estimate for the eucalypt component of Tasmanian State forest that attempts (commendably), but fails, to account for landscape age-class structure. Dean [2] overestimates CCC primarily by basing his estimate on Forest Classes 1-17. These classes are dominated by mature trees, with or without some regrowth, while Forest Classes 22-45 omitted from his calculations are dominated by immature regrowth resulting from wildfire. Comparing classes of a given height potential, Forest Classes 22-45 of course have lower $C$ densities than Forest Classes 12-17 [19] but only the area-weighted combination of all these forest classes will give an unbiased estimate of the $\mathrm{C}$ stock of natural forests. Dean then falls into the trap of comparing $\mathrm{C}$ densities of current silvicultural regeneration (Classes 50-74) only to the densities of Forest Classes at least 110 years after disturbance (Classes 1-17), which of course will overestimate $\mathrm{C}$ loss due to human activities; he admits "the areas of regeneration would not all achieve maximum C stock simultaneously," but then continues as though the numerical comparisons are valid.

Dean [2] also suggests that Moroni et al. [1] assume forests at 110 years of age are C-saturated and ecologically mature. This is clearly not the case. The 110-year age threshold that differentiates regrowth and mature forests across forest classes is inherent to the inventory dataset used, as it indicates when tree form begins to take on mature characteristics. As indicated in Moroni et al. [1], most mature forests will be significantly older than 110 years, and the inventory cohort of forests over 110 years old thus contains an area-weighted mixture of forests of all ages greater than this age, with an appropriate proportion of very old stands, and an areaweighted C stock. Sample plots are randomly located in State forest [27], rather than the "regular grid array" assumed by Dean [2].

As Dean quotes from Roxburgh [17], consideration of forest $\mathrm{C}$ stocks therefore "requires knowledge of the actual spatiotemporal variation in natural disturbance history of the forest estate, the spatiotemporal variation in other attributes relating to site quality, and the site histories from where the data were collected." Moroni et al. [1] provide this information for Tasmanian State forest. However, these real, onground data appear to be at variance with earlier assumptions as to the area of tall wet forest, which leads Dean [2] to try to locate "missing high-biomass stands," with suggested reasons including "European colonisation" or "clearing for agriculture" as much as harvesting and regeneration. Certainly, reafforestation of the rich soils of much Tasmanian agricultural land in the valleys of southern, north-eastern, and north-western Tasmania would increase landscape C stocks over the next couple of centuries, as forest grows to various stages of maturity, and provided wildfire does not intervene. However, Moroni et al. [1] did not aim to compare extant C stocks across Tasmania to some pre-European (ideal) state, restricting instead their analysis to the current situation on existing state forest. We agree with the description by Dean [2] of the need for better forest $\mathrm{C}$ accounting but the logic is even more applicable to agricultural and urban land, where the $\mathrm{C}$ deficit compared to mature forest is much greater.

The signal of past disturbances is thus present in current inventory datasets [1]. While the CCC of individual sites does not change (being the maximum value that site could carry), attainable landscape-level $\mathrm{C}$ stocks are substantially lower and cannot be estimated by the theoretical exercise of extending site CCC values across a complete forest estate that incorrectly assumes eucalypt forests can be held at maturity indefinitely. It is thus also quite inappropriate, as others have done $[2,15]$, to subtract the current $C$ content of wet eucalypt forests from an estimated CCC derived from matureforest site values, and present the answer as a putative landscape $\mathrm{C}$ loss from forest harvesting that could be sequestered back into the forest.

Lastly, Dean refers to an unpublished presentation [28] to justify his claim of little difference in long-term average C stocks depending on the initial state (age) of the forest. However, slide 51 of 62 in that presentation indicates that this result is driven by assumed large, progressive decreases in soil organic $\mathrm{C}$ on each harvesting cycle, as well as much more frequent logging than is actually planned. Losses of 30\% of soil organic C per rotation were assumed in this work and in Dean et al. [29], but amended downward over 10-fold, to $2.5 \%$, in Dean and Wardell-Johnson [30]. Unduly pessimistic assumptions in regard to forest management will lead, of course, to lower modelled carbon stores in managed forests.

2.4. Old Growth as a Reference State. Wildfire is not evenly distributed across time. Tasmania has experienced relatively low levels of wildfire since the 1960s, and no megafire of $1 \mathrm{M}$ ha or more since 1934 [31], partly because active fire 
management has reduced the impact of the 90 average annual unplanned wildfires (to an average of $\sim 10000$ ha burnt per year over the period 2003-2009: [7]). Even though as Dean [2] suggests many of the recent wildfires in Tasmanian forests are likely of European origin [31], Tasmania's natural forests are currently relatively old and C-rich, but this simply means that they will lose large amounts of $\mathrm{C}$ in the next landscapelevel wildfire.

The age-class structure of pre-European wet eucalypt forests is unknown, although it has been suggested that repeated low-intensity aboriginal burning of moorland reduced the likelihood of moorland fires escaping into eucalypt forest and potentially contributed to the infrequent but high-intensity wildfire pattern in wet eucalypt forests [31]. The total area of old growth also likely varied widely over millennia due to variation within the fire regime; similar natural, stochastic variation in the proportion of forests that are old-growth has been modelled elsewhere [32]. It is thus perverse to use old-growth stands as the reference points for carbon storage as though all forests were originally old-growth. The preEuropean age-class structure of eucalypt forests will have contained a range of ages, possibly including much open forest or young forest resulting from both wildfire and Aboriginal burning, with the overall extent of eucalypt forests being a subset of the extent of pre-European wildfire [1]. Additionally, fire danger in Australia is increasing [33], and hence with time Tasmania's forest age-class structure will likely decrease.

\section{Forest Politics}

Much of Dean [2] comprises comments on climate change, climate science, the role of forests and forestry in the global carbon cycle, forest carbon flux measurement, historical tree biomass measurements, forest allometry, the economic viability of the Tasmanian forest industry, forest politics, and Forestry Tasmania (the Tasmanian State Government Business Enterprise charged with managing State Forests). These comments are interesting, some are contentious, but are unrelated to the datasets analysed by Moroni et al. [1], so we will mostly not deal with them.

However, it is worth noting that the wider response of Dean [2] is predicated on the erroneous assumption that maximising landscape $\mathrm{C}$ storage is the sole role of forest management in greenhouse gas mitigation. The $\mathrm{C}$ footprint of active forest management in Tasmania and elsewhere needs to consider not just the long-term landscape-average $\mathrm{C}$ stocks attainable under the natural or anthropogenic disturbance regimes (wildfire or timber harvesting), but also the $\mathrm{C}$ stock in wood products, and further the $\mathrm{C}$ emissions mitigation resulting from use of timber in place of resources with higher greenhouse-gas emissions [19]. If wood was unavailable, alternative products (steel, aluminium, glass, or concrete) associated with greater greenhouse-gas emissions would be used for structural and appearance products, increasing the burning of fossil fuels both directly and indirectly: wood usage is widely recognized as being associated with lower emissions [3-5]. Wood can also be used directly as a C-neutral biofuel, with the associated $\mathrm{C}$ emission being balanced by $\mathrm{C}$ sequestration in growing trees, unlike the case with fossil fuels. The exclusion of further Australian native forests from productive usage would also lead to increased imports to supply Australian wood demands, consequently increasing emissions from increased transportation and more intensive harvesting internationally.

The misrepresentation of the Tasmanian forest industry by Dean [2] does need to be corrected for the wider audience of this journal. Dean states the Tasmanian forest industry has received repeated economic support and suggests it is financially unviable. The Tasmanian forest sector has received \$AUD 211 million in State and Commonwealth funding to compensate the industry for transferring production forests to reserves [34]. The compensation was largely used to establish plantations to offset production losses from newly reserved native forest. Income is expected from this investment as the plantation estate matures to harvest. However, more than half of the people employed in the Tasmanian timber industry depend on native forest management [35], and in 2009/2010 the estimated final value of wood products from logs sourced from native Tasmanian State forests was \$AUD 563 million [7]. Monash University estimates that Tasmania is \$AUD 111 million a year better off with Forestry Tasmania than it would be otherwise [34]. Since corporatisation 16 years ago, Forestry Tasmania has earned \$AUD 200 million in profit and has paid taxes, rates, and dividends exceeding \$AUD 99 million [34].

Lastly, Dean unreasonably criticises Forestry Tasmania for not making its data and systems freely publically available. Forestry Tasmania is a Government Business Enterprise engaged in commercial activities, and as for any company the release of datasets and systems would expose it to competitive disadvantage. One outcome would be a disincentive to continue investing in data collection and technical development, and the loss of data sets for research and collaborative research programs.

\section{Conclusions}

We have restricted our response to that part of Dean [2] relevant to the substance of our research article [1]. In essence, Dean [2] overestimates the amount of $C$ that Tasmanian wet eucalypt forests can store by assuming all stands can reach their carbon-carrying capacity (CCC) simultaneously, thereby ignoring the proportion of forests that will at any point in time be immature regrowth following wildfire. This in turn leads to an overestimation of the impact of forest management and timber harvesting on landscape $\mathrm{C}$ stocks.

Dean [2] also asserts that changes in landscape C stocks constitute the $\mathrm{C}$ footprint of forest industries, whereas a lifecycle analysis of forest and wood products shows a different picture [19]. Accounting for the direct and substitutional roles of wood products as well as landscape C stocks is necessary to determine the impact of forest management in Tasmania and elsewhere on the atmospheric levels of greenhouse gases. 


\section{Acknowledgment}

The authers would like to thank the staff from Forestry Tasmania who collected and compiled inventory data and helped locate other data related to forests and forest management in Tasmania.

\section{References}

[1] M. T. Moroni, T. H. Kelley, and M. L. McLarin, "Carbon in trees in Tasmanian State forest," International Journal of Forestry Research, vol. 2010, Article ID 690462, 13 pages, 2010.

[2] C. Dean, "Comment on "carbon in trees in Tasmanian state forest"”, International Journal of Forestry Research, vol. 2011, Article ID 212361, 10 pages, 2011.

[3] IPCC, Climate Change 2007: Mitigation of Climate Change, Contribution of Working Group III to the Fourth Assessment Report of the IPCC, 2007.

[4] FAO, "Impact of the global forest industry on atmospheric greenhouse gases," FAO Forestry 159, Food and Agriculture Organization of the United Nations, Rome, Italy, 2010, http:// www.fao.org/docrep/012/i1580e/i1580e00.htm.

[5] B. Lippke, E. ONeil, R. Harrison, K. Skog, L. Gustavsson, and R. Sathre, "Life cycle impacts of forest management and wood utilization on carbon mitigation: knowns and unknowns," Carbon Management, vol. 2, no. 3, pp. 303-333, 2011.

[6] The Wilderness Society 2011, http://www.wilderness.org .au/campaigns/forests?utm_source=topmenu\&utm_medium= web\&utm_campaign=forests, http://www.wilderness.org/campaigns/climate-change/crucial-carbon-stores.au.

[7] Forestry Tasmania, "Stewardship report 2009-2010," Forestry Tasmania, Hobart, TAS, Australia, 2010, http://www.forestrytas.com.au/uploads/File/pdf/pdf2010/stewardship_report_ 2010.pdf.

[8] Forestry Tasmania 2011, Giant Trees. http://gianttrees.com .au/.

[9] J. Norris, S. Arnold, and T. Fairman, "An indicative estimate of carbon stocks on Victoria's publically managed land using the FullCAM carbon accounting model," Australian Forestry, vol. 73, no. 4, pp. 209-219, 2010.

[10] R. G. Florence, Ecology and Silviculture of Eucalypt Forests, CSIRO Publishing, Collingwood, VIC, Australia, 1996.

[11] D. H. Ashton, "Fire in tall open-forests (wet sclerophyll forests)," in Fire and the Australian Biota, A. M. Gill, R. H. Groves, and I. R. Noble, Eds., Australian Academy of Science, Canberra, Australia, 1981.

[12] P. M. Attiwill, "Ecological disturbance and the conservative management of eucalypt forests in Australia," Forest Ecology and Management, vol. 63, no. 2-3, pp. 301-346, 1994.

[13] P. A. M. Turner, J. Balmer, and J. B. Kirkpatrick, "Standreplacing wildfires?. The incidence of multi-cohort and singlecohort Eucalyptus regnans and E. obliqua forests in southern Tasmania," Forest Ecology and Management, vol. 258, no. 4, pp. 366-375, 2009.

[14] S. H. Roxburgh, S. W. Wood, B. G. Mackey, G. Woldendorp, and P. Gibbons, "Assessing the carbon sequestration potential of managed forests: a case study from temperate Australia," Journal of Applied Ecology, vol. 43, no. 6, pp. 1149-1159, 2006.

[15] B. G. Mackay, H. Keith, S. Berry, and D. Lindenmayer, Green Carbon: The Role of Natural Forests in Carbon Storage, Australian National University Press, Canberra, Australia, 2008.
[16] H. Keith, B. Mackey, S. Berry, D. Lindenmayer, and P. Gibbons, "Estimating carbon carrying capacity in natural forest ecosystems across heterogeneous landscapes: addressing sources of error," Global Change Biology, vol. 16, no. 11, pp. 2971-2989, 2010.

[17] S. H. Roxburgh, "Increase in carbon stocks in pre-1990 eucalypt forests," in An Analysis of Greenhouse Gas Mitigation and Carbon Biosequestration Opportunities from Rural Land Use, S. Eady, M. Grundy, M. Battaglia, and B. Keating, Eds., pp. 90-100, CSIRO, St. Lucia, Australia, 2009.

[18] Government of Victoria, Living with Fire; Victoria's Bushfire Strategy, Government of Victoria, Melbourne, VIC, Australia, 2008.

[19] M. T. Moroni, "The role of forest management in greenhousegas mitigation: a contextual framework for Australia. Project No: PRC162-0910," Forest and Wood Products Australia, 2011.

[20] G. J. Nabuurs, O. Masera, K. Andrasko et al., "Forestry," in Climate Change 2007: Mitigation, B. Metz, O. R. Davidson, P. R. Bosch, R. Dave, and L. A. Meyer, Eds., Contribution of Working Group III to the 4th Assessment Report of the Intergovernmental Panel on Climate Change, Cambridge University Press, Cambridge, UK, 2007.

[21] J. R. Busby, "A biogeoclimatic analysis of Nothofagus cunninghamii (Hook.) Oerst. in southeastern Australia," Australian Journal of Ecology, vol. 11, no. 1, pp. 1-7, 1986.

[22] J. M. Gilbert, "Forest succession in the Florentine Valley, Tasmania," Papers and Proceedings of the Royal Society of Tasmania, vol. 93, pp. 129-151, 1959.

[23] W. D. Jackson, "Fire, air, water and earth-an elemental ecology of Tasmania," Proceedings of the Ecological Society of Australia, vol. 3, pp. 9-16, 1968.

[24] H. Keith, B. G. Mackey, and D. Lindenmayer, "Re-evaluation of forest biomass carbon stocks and lessons from the world's most carbon-dense forests," Proceedings of the National Academy of Sciences of the United States of America, vol. 106, no. 28, pp. 11635-11640, 2009.

[25] F. H. Bormann and G. E. Likens, Pattern and Process in a Forested Ecosystem, Springer, New York, NY, USA, 1979.

[26] C. J. Burrows, Processes of Vegetation Change, Unwin Hyman, London, UK, 1990.

[27] M. G. Stone, "Forest-type mapping by photo-interpretation: a multi-purpose base for Tasmania's forest management," Tasforests, vol. 10, pp. 15-32, 1998.

[28] C. Dean and G. Wardell-Johnson, "Effective carbon management of forests requires recognition of major pools and timelines," in Proceedings of the the Adapting Forest Management to Maintain the Environmental Services: Carbon Sequestration, Biodiversity and Water, Koli National Park, North Karelia, Finland, September 2009.

[29] C. Dean, S. H. Roxburgh, and B. G. Mackey, "Growth modelling of Eucalyptus regnans for carbon accounting at the landscape scale," in Modelling Forest Systems, A. Amaro, D. Reed, and P. Soares, Eds., pp. 27-39, CAB International, Wallingford, UK, 2003.

[30] C. Dean and G. Wardell-Johnson, "Old-growth forests, carbon and climate change: functions and management for tall openforests in two hotspots of temperate Australia," Plant Biosystems, vol. 144, no. 1, pp. 180-193, 2010.

[31] J. B. Marsden-Smedley, "Changes in southwestern Tasmanian fire regimes since the early 1800s," Papers and Proceedings of the Royal Society of Tasmania, vol. 132, pp. 15-29, 1998. 
[32] M. C. Wimberly, T. A. Spies, C. J. Long, and C. Whitlock, "Simulating historical variability in the amount of old forests in the Oregon Coast Range," Conservation Biology, vol. 14, no. 1, pp. 167-180, 2000.

[33] C. Lucas, K. Hennessy, G. Mills, and J. Bathols, 2007, Report to the Climate Institute of Australia. http://www.bushfirecrc .com/research/downloads/climate-institute-report-september2007.pdf.

[34] State of Tasmania, “Auditor general," Tech. Rep. 100, Financial and Economic Performance of Forestry Tasmania, Hobart, TAS, Australia, 2011.

[35] J. Schirmer, Tasmania's Forest Industry: Trends in Forest Industry Employment and Turnover, 2006-2010, CRC for Forestry, Hobart, TAS, Australia, 2010. 

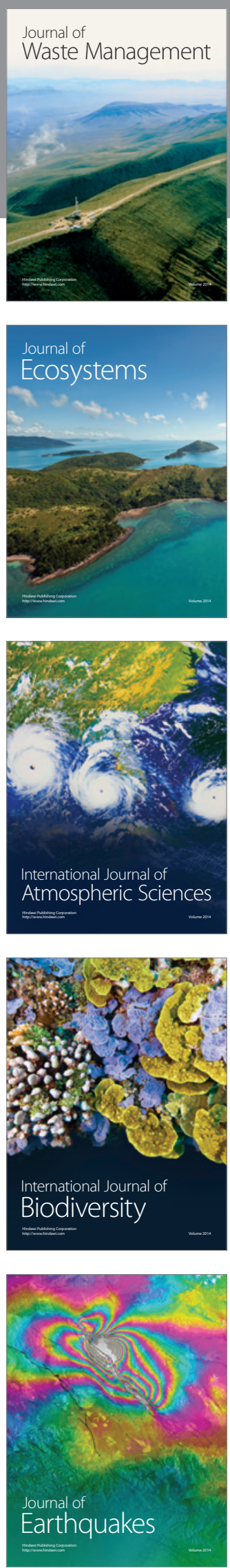
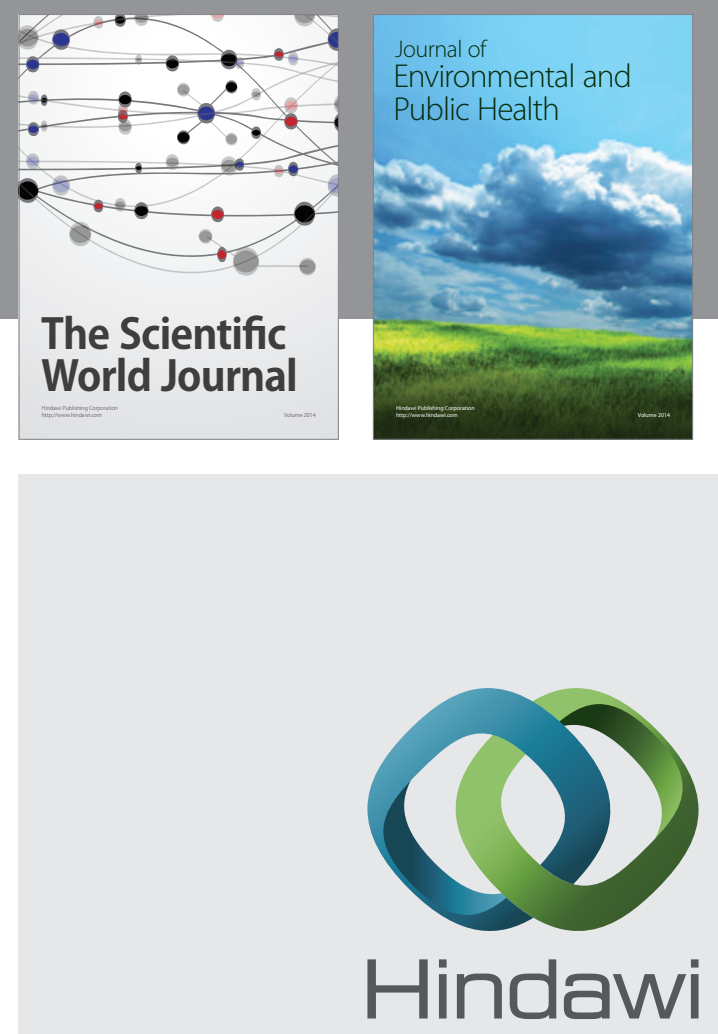

Submit your manuscripts at

http://www.hindawi.com
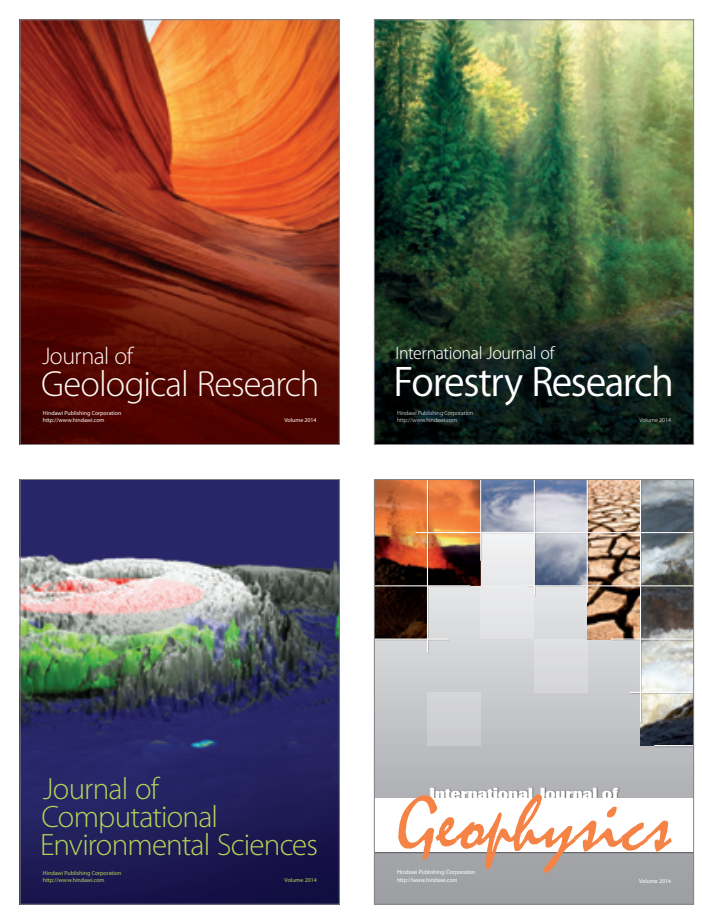
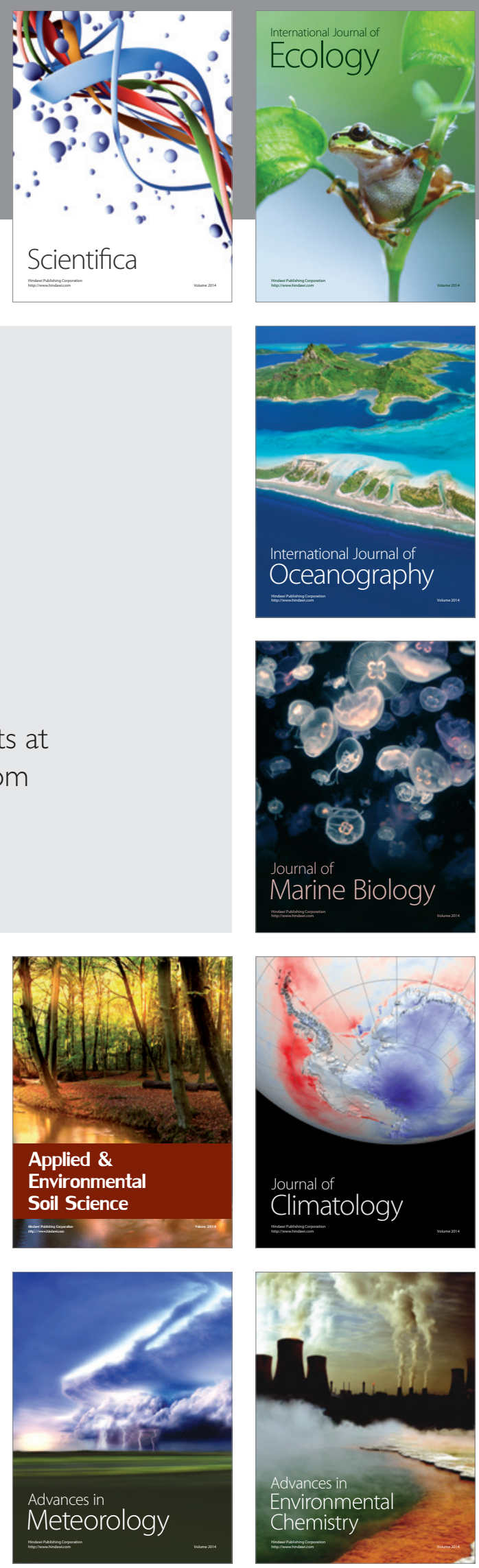